\title{
Soil Suppressiveness Against the Disease Complex of the Soybean Cyst Nematode and Sudden Death Syndrome of Soybean
}

\author{
Andreas Westphal and Lijuan Xing
}

First author: Julius Kühn-Institut, Federal Research Centre for Cultivated Plants, Institute for Plant Protection in Field Crops and Grassland, D-48161 Münster, Germany; and second author: Syngenta Seeds Inc., Bay, AR 72411. Accepted for publication 27 January 2011.

\section{ABSTRACT}

Westphal, A., and Xing, L. J. 2011. Soil suppressiveness against the disease complex of the soybean cyst nematode and sudden death syndrome of soybean. Phytopathology 101:878-886.

\begin{abstract}
The ecology of the complex of soybean cyst nematode (SCN) and sudden death syndrome (SDS) of soybean was investigated under soybean monoculture in two field experiments from 2003 to 2007. Initially, susceptible soybean 'Spencer' was planted while inoculating Fusarium virguliforme into nonfumigated or preseason-fumigated plots (methyl bromide, MB, at $450 \mathrm{~kg} / \mathrm{ha}$ ), and SCN and SDS were monitored. In one field, SCN population densities declined in nonfumigated but increased in fumigated plots. After years of limited SDS in 2003 and 2004, SDS developed later in nonfumigated than fumigated plots. In 2006 in the greenhouse, nondisturbed or disturbed soil cores (10-cm diameter,
\end{abstract}

30-cm depth) from field plots received two two-level factors: (i) nonfumigated or fumigated $(1,070 \mathrm{~kg} / \mathrm{ha} \mathrm{MB})$; and (ii) noninoculated or inoculated with 9,000 second-stage juveniles of SCN. At harvest, nonfumigated cores from nonfumigated plots had fewer nematodes and less SDS regardless of disturbance or inoculation than the corresponding fumigated cores and any cores from fumigated plots. In the second field, SCN became detectable after 2003 during the monoculture in nonfumigated plots and lagged in fumigated plots; both treatments had low levels of SDS. Exploiting the suppressiveness of the first field could allow for biological control of SDS and SCN in soybean production.

Additional keywords: antiphytopathogenic potential, biological control, Glycine max, soilborne pathogens.
Soil suppressiveness has been investigated for several decades. Based on early definitions (3), such soils "do not allow a pathogen to establish; they allow for the pathogen to establish but not to cause disease; or they allow for initial pathogen establishment and severe disease and then diminished disease severity with continued cropping of the host." Suppressive soils have been identified that effectively reduce pathogens or disease severity in a number of pathosystems, including prokaryotes, e.g., Ralstonia solanacearum-suppressive soil in tomato (35); streptomycetes, e.g., Streptomyces scabies in potato $(30,44)$; oomycetes, e.g., Aphanomyces euteiches in pea (38), Phytophthora cinnamomi in trees (4); Plasmodiophoromycetes, e.g., Plasmodiophora brassicae in Chinese cabbage (31); ascomycetes, e.g., Sclerotinia trifoliorum in clover (39), and Helminthosporium solani in potato (26); basidiomycetes, e.g., Rhizoctonia solani in various crops (8); hyphomycetes, e.g., Fusarium wilt suppressive soils (1); plant-parasitic nematodes, cyst nematodes $(6,20,21,50,54)$, and root-knot nematodes $(22,40,47)$ in diverse crops.

Some associations of soil suppressiveness with soil physical and chemical properties have been reported. For example, higher aggregate stability led to anaerobic microhabitats with increased Fe availability resulting in more severe Fusarium wilt of banana, whereas amendments with $\mathrm{Ca}$ in different forms reduced severity of this disease $(12,37)$. Different clay minerals with corresponding soil texture and $\mathrm{pH}$ were identified as important in the suppression of Fusarium wilt of flax (19). But most soil suppressiveness studies have focused on microbial modes of action $(15,28,51,52)$. The examples of suppressive soils have in common that the suppressiveness was effective against one or several

Corresponding author: A. Westphal; E-mail address: andreas.westphal@jki.bund.de

doi:10.1094/PHYTO-09-10-0245

(C) 2011 The American Phytopathological Society pathogens of a single kingdom. Biocontrol organisms from suppressive soils have been shown to be effective to more plant pathogens than those for which they were first identified. For example, some beneficial Streptomyces strains isolated from potato scab-suppressive soils also suppressed Phytophthora or root lesion nematodes $(45,60)$. But not a single example has been documented that refers to a soil suppressive against a disease complex or against pathogenic organisms from different kingdoms.

Sudden death syndrome (SDS) of soybean (Glycine max), caused by Fusarium virguliforme $(2,10)$, formerly $F$. solani $\mathrm{f}$. sp. glycines (41), combined with the soybean cyst nematode ( $\mathrm{SCN}$ ), Heterodera glycines, cause the most yield losses of soybean in the United States (59). Although the fungal pathogen causes the disease by itself, $H$. glycines increases the severity of foliar symptoms of SDS synergistically and SDS could be considered a disease complex of $F$. virguliforme and $H$. glycines based on microplot experiments (61). Management strategies for $H$. glycines and SDS are categorized into the use of host plant resistance, chemical control, biological control, and cultural practices $(17,32)$. Sustainability of the use of host plant resistance is at risk because the nematode occurs in various genetically distinct populations (HG types) that are capable of reproducing on plant genotypes with specific sources of resistance (33), and that isolates of the fungal pathogen differ in virulence $(18,23)$. The relationship of increasing $H$. glycines population densities with decreasing soybean yields was acknowledged (34), but no such relationship was defined for SDS. No biological or chemical control options for the SDS disease complex are currently recommended.

Crop rotation has been a major tool for managing the risk for crop damage by soilborne plant pathogens. The rotation of soybean with nonhost crops, e.g., wheat, reduced population densities of both $H$. glycines and $F$. virguliforme, and yields of a following 
SDS-susceptible soybean crop were increased after wheat or fescue compared with continuous soybean in Arkansas (43). The Midwest-typical rotation of soybean with corn was not beneficial in reducing SDS and may even increase the disease severity (63). No-tillage is thought to keep $H$. glycines population densities at low levels and to reduce nematode damage $(57,58)$. The impact of tillage on SDS is not clear: in some instances no-tillage promoted SDS (49), hypothetically because of higher soil moisture content for longer periods than under tillage systems with more intensive soil disturbance; but in recent studies, severity of SDS was reduced under continuous no-tillage (46). Much more information on the ecology of the disease complex of SDS is needed for the design of sustainable management systems.

The objective of the current study was to determine the development of population densities of $H$. glycines and the severity of SDS in soil with its resident microbial communities or equivalent fumigated soil under monoculture of susceptible soybean.

\section{MATERIALS AND METHODS}

Field trials. Two field trials were established in 2003, one at the Agronomy Center for Research and Education (ACRE), just north of West Lafayette, IN in a silt clay loam soil (20\% sand; $50 \%$ silt; $30 \%$ clay; $\mathrm{pH} 6.0 ; 1.7 \%$ organic matter), and a second trial near Romney, IN at the Throckmorton Purdue University Agricultural Center (TPAC) in a Toronto-Millbrook silt clay loam (8\% sand; $60 \%$ silt; $32 \%$ clay; $\mathrm{pH} 6.1 ; 2.0 \%$ organic matter). In years previous to the experiments, both sites had been under field crop cultivation, mostly soybean and corn with occasional interruption by small grains. After spring chisel plowing to $25-\mathrm{cm}$ depth, trial areas were established in four replicate blocks in each field. At each location, plots consisted of 15-m long and $7.5 \mathrm{~m}$ (ACRE) or $15 \mathrm{~m}$ (TPAC) wide areas. Two treatments were applied in randomized complete block design. On 23 May 2003, one plot per block was fumigated with methyl bromide (98\% methyl bromide and $2 \%$ chloropicrin) at $450 \mathrm{~kg} / \mathrm{ha}$ with a commercial applicator and covered with high barrier plastic film $(0.025-\mathrm{mm}$ thickness, Hendrix and Dail, Paris, IL) during fumigant application. The nonfumigated plots of each block were chiseled with the application rig without dispensing fumigant to generate similar soil tilth in both treatments. The tarp was cut on 28 May 2003, and removed from the plots on 30 May 2003.

On 9 June 2003, nonfumigated and fumigated plots were infested with $F$. virguliforme on grain sorghum during planting by a method similar to the one described previously (11). During planting of the $76-\mathrm{cm}$ center-to-center rows, a modified commercial planter concurrently dispensed $5.25 \mathrm{~g}$ of grain sorghum inoculum per meter of row (equivalent to $68.5 \mathrm{~kg} / \mathrm{ha}$ ) with a granular applicator (Gandy Co., Owatonna, MN) 7.5-cm deep immediately in front of the planter unit with disk applicator shanks underneath the future soybean row. The grain sorghum had been colonized with $F$. virguliforme in laboratory culture. Plots were planted with untreated seeds of soybean 'Spencer' susceptible to both $F$. virguliforme and $H$. glycines at 370,650 seeds/ha. On 23 July 2003, nitrogen (112 kg/ha) was uniformly applied to all plots to mitigate the differences of frequency of the symbiont in nonfumigated and fumigated plots. In May of the years 2004 to 2007, seed of 'Spencer' inoculated with Rhizobium spp. (Cell Tech Soybean; EMD Crop BioScience, Brookfield, WI) was planted at similar plant population densities into the seeding rows originally established in 2003 using no-till planting equipment. Weeds were controlled with a herbicide program recommended for non-Roundup Ready soybean (24) and additional hand weeding. Severity of foliar symptoms of SDS on a scale of 0 to 9 ( 0 , healthy to 9 , premature death) and root necrosis on a scale of 1 to 5 (1, healthy to 5 , entirely necrotic) at R3 through R6 were assessed $(14,25,61)$. At ACRE in 2005, only one late foliar rating
(25 August) was done; in 2006 and 2007, early, medium, and late ratings of the soybean tops and roots were done (2006: 26 July, 12 August, and 29 August, or 2007: 13 August, 21 August, and 28 August). At TPAC in 2005, one very late rating was taken (11 September); in 2006, late and very late ratings were taken (25 August and 5 September); and in 2007, a late rating (27 August) was taken. Soil samples for determining population densities of $H$. glycines were taken every year at planting and at harvest in the form of a total of 20 cores $30-\mathrm{cm}$ deep from the root zone from each plot with a 19-mm diameter Oakfield sampling tube. Cyst nematodes were extracted from 500-g soil samples with an elutriator (5); cysts and eggs were counted using standard procedures (13). At maturity, grain was harvested with a smallplot combine with electronic weighing and moisture determination equipment (Almaco, Nevada, IA). Grain weights were converted to yields in kilogram per hectare at $13 \%$ moisture before analysis.

Greenhouse experiment. In the spring of 2006 before planting the field plots at ACRE, undisturbed soil cores of $10-\mathrm{cm}$ diameter and $30-\mathrm{cm}$ depth were collected from each of the four blocks. For this purpose, a metal soil core sampling template containing 10 -cm-diameter thin-walled PVC pipe precut at $10-\mathrm{cm}$ depth layers was fitted to a hydraulic soil sampler (Giddings Machine Co., Fort Collins, CO). In each plot, the soil core sampler was inserted at four locations for pairs of undisturbed and corresponding disturbed cores in an arbitrary pattern. When excavating the undisturbed soil core, soil from immediately adjacent to the undisturbed core was dug out in layers of 0 to 10,10 to 20 , and 20 to $30 \mathrm{~cm}$ depth separately, and passed through a $6.3-\mathrm{mm}$ aperture sieve. Soil was mixed within these depth layers and packed at the respective original depth into PVC pipes same as those containing the undisturbed samples. The PVC pipes were fitted at the bottom with a lid with holes allowing for drainage and lined with fiberglass netting served as pots during greenhouse incubation. Population densities of $\mathrm{H}$. glycines in each of the soil layers were determined from additional composite soil on a plot basis. At the sampling time for the greenhouse experiment, penetrometer readings were taken at nine arbitrary spots per plot at both locations with an electronic cone penetrometer (CP40II, RFM Australia Pty Ltd., Toowoomba, AU) to a depth of $45 \mathrm{~cm}$.

In the greenhouse, two more factors were superimposed to random pairs of undisturbed and disturbed soil cores from each of the nonfumigated and fumigated field plots at ACRE. In factorial design considering the field fumigation and collection method, soil cores were as follows: (i) nonfumigated or fumigated with methyl bromide (98\% methyl bromide and $2 \%$ chloropicrin) at $1,070 \mathrm{~kg} / \mathrm{ha}$; and (ii) noninfested or infested with 9,000 secondstage juveniles (J2) of $H$. glycines. Fumigant applications were done in a chamber designed for fumigation treatments at the Purdue University, West Lafayette campus. The PVC pipes containing soil cores collected from the fields were taped to reduce gas exchange, and methyl bromide was injected through a selfsealing membrane (Alltech, Deerfield, IL) attached to the 0.01-mm plastic tarp at the top of the soil core with a gas tight syringe (Hamilton Company, Reno, NV). After aeration, soil cores were arranged in a randomized complete block design on a greenhouse bench and a drip irrigation system installed. Four twoday-old pregerminated seeds of 'Spencer', surface-disinfested and inoculated with the commercial formulation of Rhizobium spp., were planted into the center of each soil core at 2-cm depth. After emergence, seedlings were thinned to one plant per pot. On 5 June 2006, 9,000 J2 of $H$. glycines ( $\mathrm{HG}$ type 2.5.7) from greenhouse cultures and applied in $10 \mathrm{ml}$ of water into two $1-\mathrm{cm}$ diameter and $15-\mathrm{cm}$ deep grooves half way between the soybean plant and the pot rim. Liquid applications of Miracle Grow (Scott Miracle Gro Products, Inc., Marysville, OH; $15.0 \%$ N, $13.1 \%$ P, and $12.5 \% \mathrm{~K}$ ) were made weekly at the amount for optimum plant growth. 
After 2 months, the experiment was harvested. Plant tops were rated for severity of foliar symptoms of SDS on a scale of 0 to 9 and oven dry-weighed. Soil cores were divided into the three predetermined depth-layers, which were processed separately for root and cyst extraction. Within each depth-layer of each soil core, roots were cut into 2 to $3 \mathrm{~cm}$ pieces to allow for homogenizing, and soils were thoroughly mixed. Soils were weighed, and subsamples of soil and root were processed further. Subsamples of $150 \mathrm{~g}$ of soil were used for root extraction and length measurements as described previously (56), which was a modification of McMichael and Burke (29). Root samples were stored at $4^{\circ} \mathrm{C}$ until being measured with a computer-based flat-bed scanner (WinRhizo, Regent Instruments, Quebec, Canada). The lengths of roots with diameters $\leq 3 \mathrm{~mm}$ was recorded and entered into statistical analysis. Thicker roots were omitted from the analysis because they occurred rarely or in low amounts only in some treatments. Cysts were extracted from soil samples following the procedures outlined above.

Statistical analysis. All soil-related counts were converted to numbers per $100 \mathrm{~g}$ of soil. Analysis of variance (ANOVA) was done using the general linear model (GLM) in SAS (SAS 9.1; SAS Institute, Cary, NC). Some data were transformed before analysis to improve the homogeneity of error variances: ratings

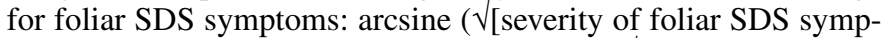

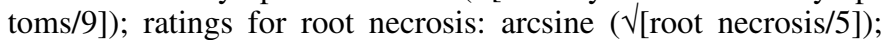
and nematode counts: $\log _{10}$ (counts +1 ). For the field experiments, yields and nematode numbers at harvest were entered into a splitplot model with year as a fixed effect to evaluate population dynamics over time; error terms were pooled where possible. In the greenhouse experiment after the proper pooling of the error terms in the model, soil depth-related measures were analyzed with a split-split plot design. For all mean comparisons, the appropriate least significant differences were calculated to compare means and were computed in PROC MIXED of SAS at $P=$ 0.05 unless otherwise indicated.

\section{RESULTS}

At ACRE. In 2003 and 2004, traces of the SDS were detected in nonfumigated plots only; beginning in 2005 at each rating time, foliar symptoms of SDS were more severe in fumigated than in nonfumigated plots (Fig. 1A). In 2006, no foliar symptoms of SDS were detected in nonfumigated plots at the early rating time, some at the medium rating time, and more at the late rating time,

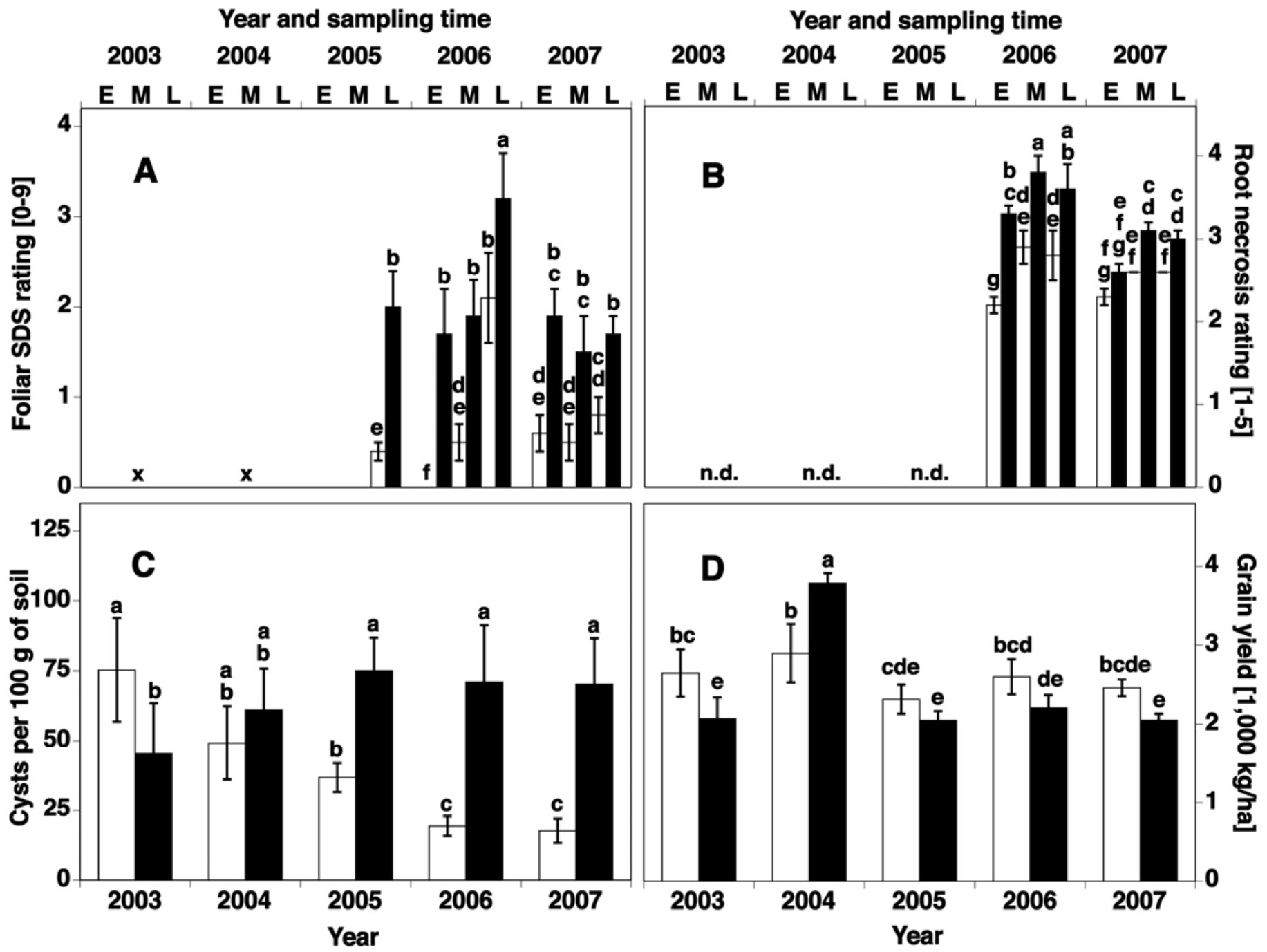

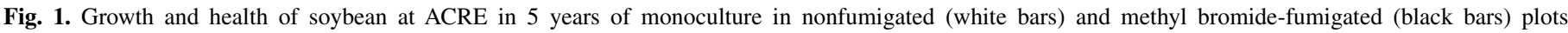

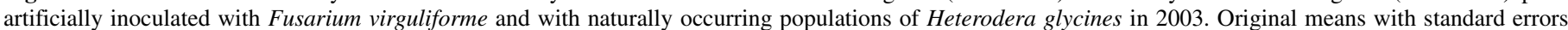

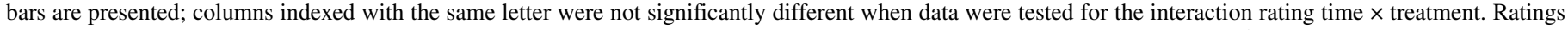

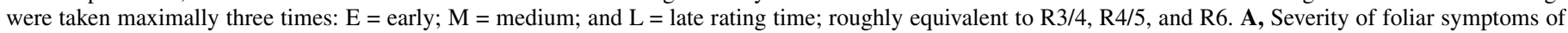

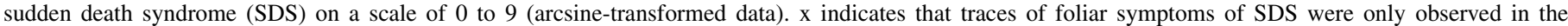

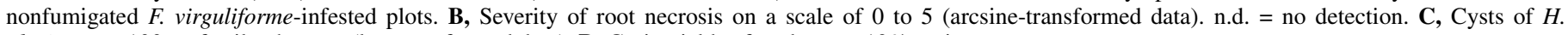
glycines per $100 \mathrm{~g}$ of soil at harvest (log-transformed data). D, Grain yields of soybean at $13 \%$ moisture content. 
but much more severe foliar symptoms of SDS were observed in the fumigated plots at each rating time (Fig. 1A). In 2007, severity of foliar symptoms of SDS was similar among the different rating times within each of the two treatments, but significantly different and higher in the fumigated than the nonfumigated plots at each rating time (Fig. 1A). Root necrosis was only rated in 2006 and 2007. In both years, root necrosis was more severe in the fumigated plots than in the nonfumigated plots at most of the sampling times (Fig. 1B). In 2006 from the early to the late sampling time, the root necrosis was consistently more severe in fumigated than in nonfumigated soil, where the roots were more necrotic at later than early rating times. In 2007 after similar levels at early sampling, severity of root necrosis increased significantly in the fumigated plots while it remained lower in nonfumigated plots (Fig. 1B). Cyst population densities of $H$. glycines continuously declined from 2003 to 2007 in nonfumigated plots but increased in the fumigated plots. In 2003, cyst population densities were higher in the nonfumigated soil than in the fumigated soil but continued to decline afterwards. In fumigated soil, population densities kept increasing from 2003 to 2005 , exceeded those in the nonfumigated soil in 2004, reached the highest level in 2005, and remained stable subsequently (Fig. 1C). Averaged for all years, yields were $2,583 \mathrm{~kg} / \mathrm{ha}$ in the nonfumigated plots and $2,431 \mathrm{~kg} / \mathrm{ha}$ in the fumigated plots. Yields in the fumigated plots were lower in 2003, but surpassed those in the nonfumigated plots in the 2004, and then declined to the level even below the yield in the nonfumigated plots in 2005 (Fig. 1D). Averaged for the 3 years (2005 to 2007) when severity of foliar symptoms of SDS and population densities of $H$. glycines were less in the nonfumigated than those in the fumigated plots, yields were higher in nonfumigated plots than in the fumigated plots $(2,458$ versus $2,099 \mathrm{~kg} / \mathrm{ha} ; P<0.01)$.

At TPAC. At this location, ratings for foliar symptoms of SDS and for root necrosis were conducted later than at ACRE. Severity of foliar symptoms of SDS between the nonfumigated and the fumigated plots were mostly similar within a rating time and a year from 2005 to 2007. Only at the late rating time in 2006, more foliar symptoms of SDS were detected in the fumigated plots than in the nonfumigated plots (Fig. 2A). Root ratings ranged from 2.8 (late 2007) to 3.1 (very late 2005) and were similar in the nonfumigated and fumigated plots (Fig. 2B). Cyst nematode populations were not found in the nonfumigated or fumigated plots in

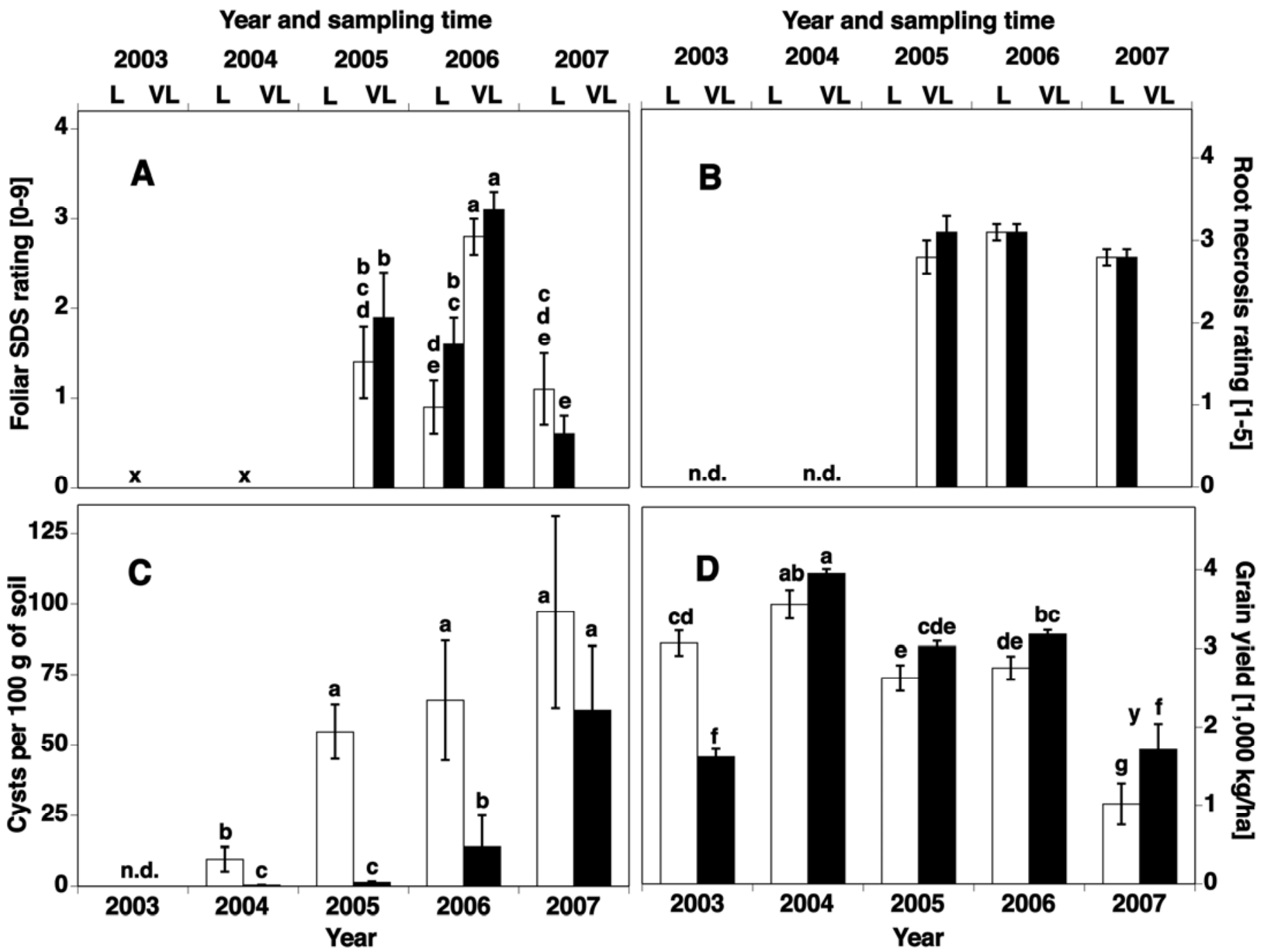

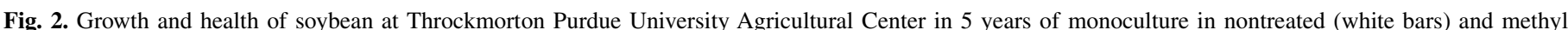

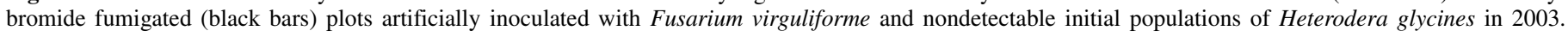

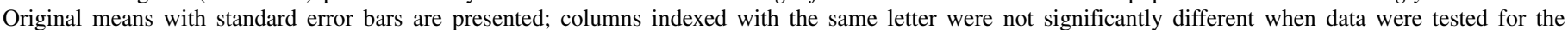

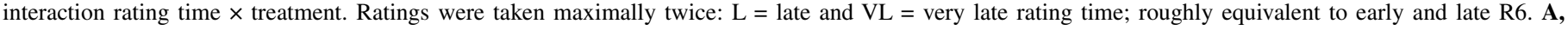

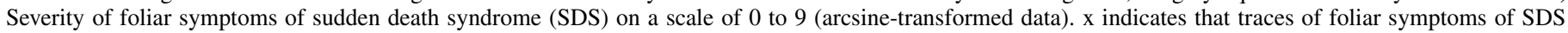

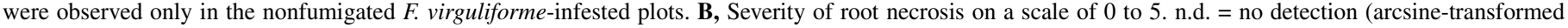

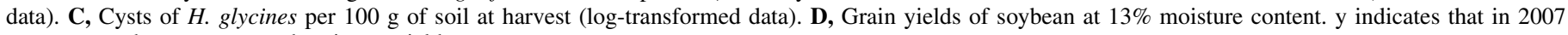
extreme weed cover prevented optimum yields. 
2003, but became detectable in the nonfumigated plots in 2004, and continuously increased from 2005 to 2007 . In the fumigated plots, the cyst population densities in the soil in 2004 and 2005 were low, but increased in 2006, and reached similar levels to those in the nonfumigated plots in 2007 (Fig. 2C). Yields in the fumigated plots were numerically higher than in the nonfumigated plots in all years except in 2003; only in 2006 and 2007 was the difference of yields between the two treatments significant (Fig. 2D). Yields in 2007 were low because of probably excessive weed pressure.

Penetrometer readings. Analysis of the cone penetrometer readings collected from the experiments at ACRE and TPAC could not be combined, but the readings were similar between the two locations and followed the same general pattern in both nonfumigated and fumigated plots in each location, where penetration resistance increased continuously with increasing depths (Fig. 3).

Greenhouse experiment. At harvest of the greenhouse experiment, dry weights of plant tops were highest in the fumigated soil cores from fumigated field plots and lowest in the nonfumigated soil cores from fumigated field plots (Table 1). Plants that grew in soil cores that had been fumigated after transfer from field plots to the greenhouse did not show any foliar symptoms of SDS (Table 1). When soil cores from field plots were left nonfumigated after transfer to the greenhouse, foliar symptoms of SDS was more severe if the soil cores were collected from fumigated field plots rather than from the nonfumigated field plots (Table 1).

Before initiation of the greenhouse experiment, cyst population densities of $H$. glycines were significantly higher in fumigated than nonfumigated plots $(P<0.01)$ and were stratified by soil depth with less cyst densities in the deeper layers than in the shallow layers (Fig. 4A). Averaged across depths, there were more cysts per $100 \mathrm{~g}$ of soil in the fumigated plots than in the nonfumigated $(P<0.01)$ and averaged across treatments, there were more cysts in shallower layers than in deeper layers $(P<$ $0.01)$. The interaction of the treatment $\times$ depth was not significant $(P=0.2467$, data not shown), indicating that the same distribution patterns were observed for both treatments. Similar patterns were observed for the nematode eggs ( $\log _{10}$-transformed: $P_{\text {treatment }}<$ $0.01 ; P_{\text {depth }}<0.01 ; P_{\text {treatment } \times \text { depth }}=0.1340$; data not shown).

At harvest of the nematode-inoculated cores, overall population densities of the cysts were higher in disturbed than nondisturbed soil cores (Fig. 4B; Table 2). Within the nondisturbed cores collected from nonfumigated field plots, fewer cysts were found in the nonfumigated soil cores $(P=0.10)$ than in the fumigated

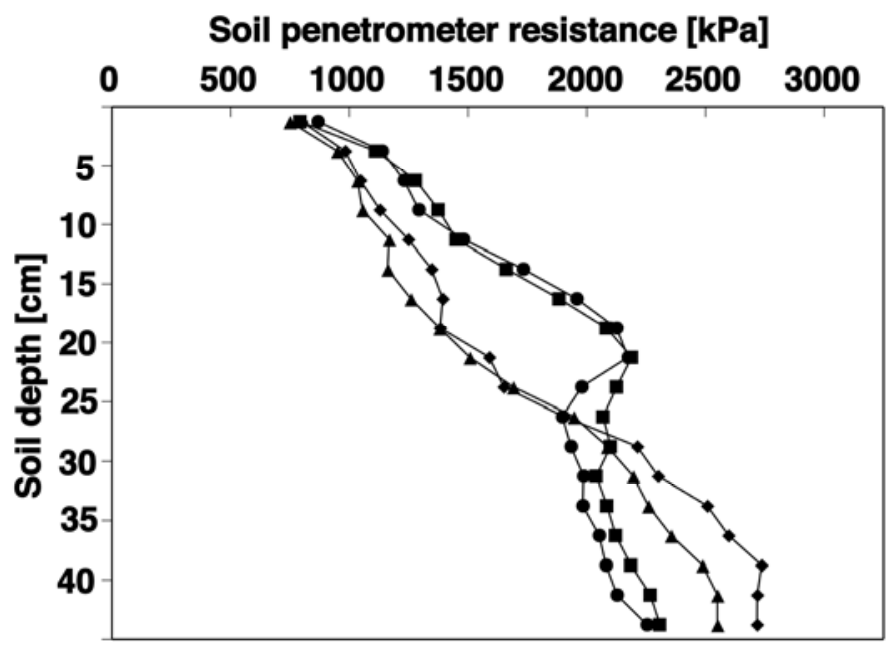

Fig. 3. Cone penetrometer resistance of field plots with soybean monoculture at both Agronomy Center for Research and Education (ACRE) and Throckmorton Purdue University Agricultural Center (TPAC) in 2006. ACRE: $\boldsymbol{\Delta}=$ nonfumigated and $\boldsymbol{\nabla}$ = fumigated with methyl bromide in 2003; and TPAC: $\boldsymbol{\square}=$ nonfumigated and $\bullet$ = fumigated with methyl bromide in 2003 . equivalents. Nondisturbed soil cores derived from fumigated field plots supported similar levels of cysts independent of greenhouse fumigation treatment (Fig. 4B). A similar pattern to those in the nondisturbed soil cores was found in the disturbed cores with fewer cysts found in the nonfumigated soil cores than in the fumigated equivalents $(P<0.01)$. Overall, population densities of the eggs were not significantly different between the nondisturbed and the disturbed cores (Fig. 4C, Table 2), but in the disturbed cores from the nonfumigated field plots, lower egg population densities were found in the nonfumigated cores than the fumigated equivalents $(P<0.01$; Fig. 4C). Averaged over all treatments, more roots were extracted from the nondisturbed soil cores than from the disturbed soil cores $(850$ versus $805 \mathrm{~cm}$ per $100 \mathrm{~g}$ of soil; $P=0.02$; data not shown). In the nondisturbed soil cores, root lengths were similar among all the compared treatments, while in the disturbed soil, the fumigated soil cores had fewer roots than the nonfumigated equivalents independent of field treatments $(P<0.01$; Fig. 4D). The same differences as described for population densities per $100 \mathrm{~g}$ of soil were also observed when population densities were calculated per $100 \mathrm{~cm}$ of root length with the exception that the numbers in the nonfumigated cores from the nonfumigated field soil were significantly lower than in the fumigated equivalent $(P=0.05$; data not shown).

When all factors were included in the model (field fumigation $x$ collection method $\times$ depth $\times$ greenhouse fumigation $\times$ nematode inoculation), further patterns were detected. The numbers of cysts per $100 \mathrm{~g}$ of soil were not increased when nonfumigated soil cores from the nonfumigated field plots were inoculated compared with the noninoculated equivalents; population densities increased greatly when soils were fumigated before set-up in the greenhouse in this same comparison (data not shown). The number of eggs per $100 \mathrm{~g}$ of soil increased in all treatments after inoculation except in the nonfumigated soil cores from the nonfumigated field soils (data not shown).

\section{DISCUSSION}

In the third year of monoculture of soybean 'Spencer' susceptible to both pathogens of the disease complex of SDS and $\mathrm{SCN}$, a suppressive soil developed when both pathogens were initially present above detection levels at ACRE. Although the

TABLE 1. Soybean top dry weights and severity of foliar symptoms of sudden death syndrome (SDS) in nonfumigated and fumigated soil cores from nonfumigated and fumigated soybean monoculture field plots in a greenhouse experiment $^{\mathrm{W}}$

\begin{tabular}{lcccc}
\hline \multicolumn{2}{c}{ Fumigation treatments $^{\mathrm{x}}$} & & $\begin{array}{c}\text { Top dry } \\
\text { weight }(\mathrm{g})\end{array}$ & $\begin{array}{c}\text { Foliar SDS } \\
(0 \text { to } 9)^{\mathrm{y}}\end{array}$ \\
\cline { 1 - 2 } Field (2003) & Greenhouse (2006) & & $32.3 \pm 2.2 \mathrm{ab}$ & $1.0 \mathrm{~b}$ \\
- & - & $32.0 \pm 1.9 \mathrm{ab}$ & $0.0^{\mathrm{z}}$ \\
- & + & $27.6 \pm 2.8 \mathrm{~b}$ & $3.1 \mathrm{a}$ \\
+ & - & $36.0 \pm 2.1 \mathrm{a}$ & $0.0^{\mathrm{z}}$ \\
+ & + & & \\
& & & 6.5 & 1.8 \\
LSD $_{0.05}$ & $\ldots$ & 0.0497 & 0.0227 \\
\hline
\end{tabular}

w Original means and standard errors of the fumigation treatments averaged across collection method and inoculation with Heterodera glycines are presented. Numbers within each column followed by the same letter are not significantly different at $P=0.05$.

$x$ Soil cores, collected from the nonfumigated (-) and fumigated (+) field plots, were either nonfumigated (-) or fumigated $(+)$ in the greenhouse after transfer from field to the greenhouse. The fumigation was conducted with methyl bromide at $450 \mathrm{~kg} / \mathrm{ha}$ in the field in 2003 , or during transit into the greenhouse at $1,070 \mathrm{~kg} / \mathrm{ha}$ in 2006 .

y Original means and statistical parameters are shown. Analysis of the arcsinetransformed data had the same outcome.

${ }^{\mathrm{z}}$ No foliar symptoms of SDS were detected. These treatments were excluded from analysis of variance. 
decline of plant disease severity under monoculture of the hosts of the primary pathogens has been described for nematodes or for fungal diseases $(9,20)$, this phenomenon had not been known for disease complexes of agricultural production systems. Typically, suppressive soils are inhibiting pathogens within one kingdom or lower taxa. For example in root rot of pea, soils varied for suppressiveness to the groups of potential root rotters independently, but yet these pathogens belonged to the same kingdom (36). In our studies, soil suppressiveness only developed when both pathogens of the SDS disease complex were present from the beginning of the experiment (ACRE); when the pathogens were not detectable or at very low levels, no suppressiveness was observed but instead a steady increase of the population densities of $H$. glycines (TPAC). Our data supported the concept put forward by Cook and Baker (9) that the disease-causing organism(s) and a susceptible host must be present for soil suppressiveness to develop.

The development of soil suppressiveness against the SDS disease complex was surprising because many cyst nematodesuppressive soils are based on fungal activity $(21,64)$ and soils suppressive to fungal pathogens appear to be frequently bacterial based (51). If known modes of action were responsible for this suppressiveness a conceptual challenge arises: how can the microbial community in this suppressive soil manipulate the fungal community in the soil in two opposite ways simultaneouslypromote the beneficial fungi, which suppress $H$. glycines and inhibit the plant-pathogenic $F$. virguliforme? The interactions are further complicated due to the ability of $F$. virguliforme to colonize cysts of $H$. glycines (42). Antagonism of this colonization against the cyst nematode cannot be discounted although no indication for such effect was found in our study. The data did not exclude the possibility that suppression of the SDS disease complex was mediated by the reduction of $H$. glycines and thus weakening its fungal disease-supporting role. The potential for such indirect suppression of SDS via suppression of $H$. glycines has been demonstrated when $H$. glycines was suppressed by the nematicide aldicarb in fields with a history of SDS (46).

The design of the current study followed the concept that a susceptible host is necessary to promote the development of soil suppressiveness. In general, it was surmised that the plant genotype was important for the development of soil suppressiveness $(15,27,28)$ and also for the maintenance of the suppressive properties of the soil (55). In Indiana in field experiments with natural populations of both $F$. virguliforme and $H$. glycines, soybean monoculture was also found to be effective in reducing severity of SDS or population densities of SCN compared with soybean-corn rotation (63). Van Elsas et al. (48) illustrated the impact of agronomic practices on the development of soil sup-
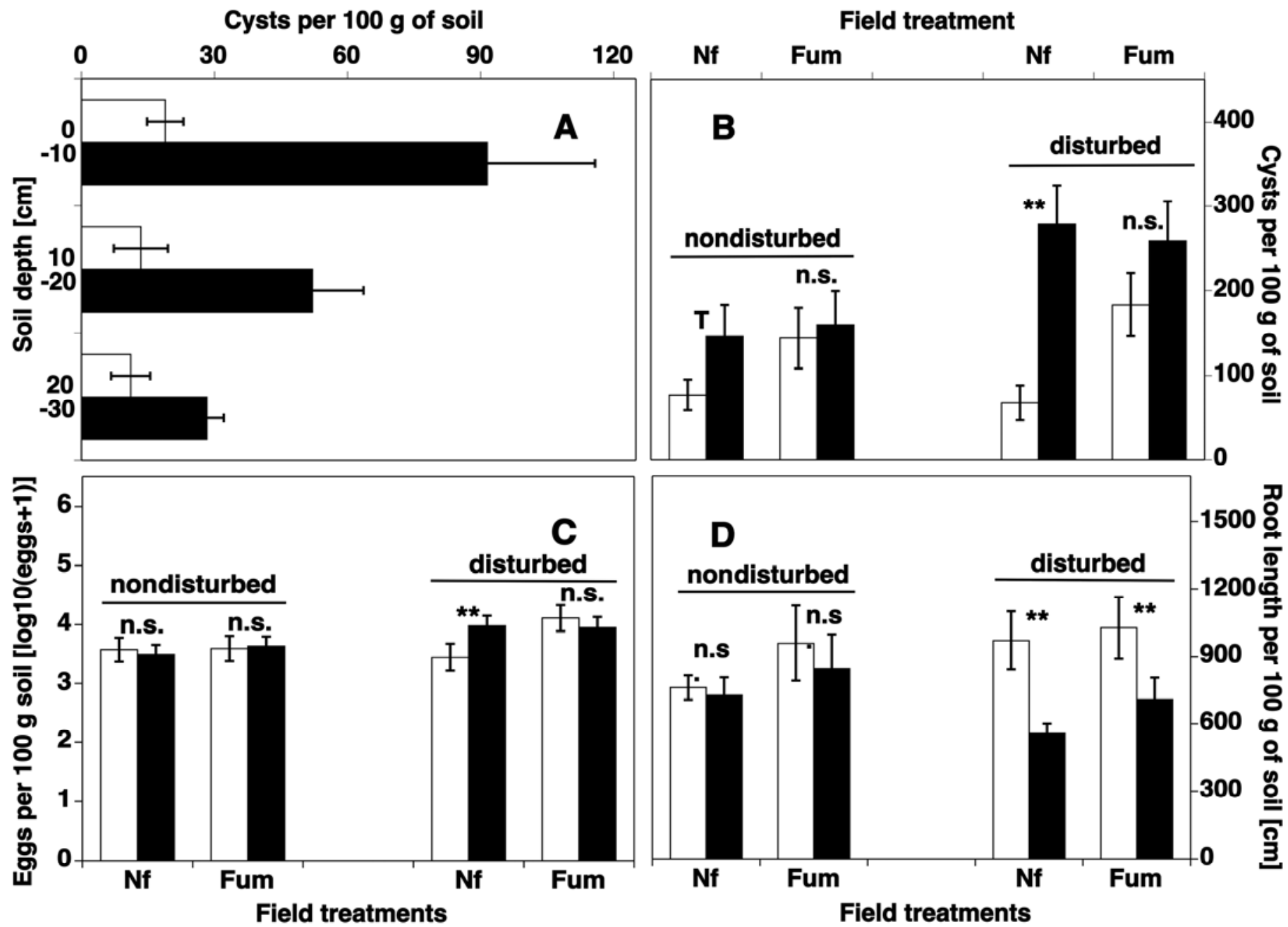

Field treatments

Field treatments

Fig. 4. Greenhouse experiment in 2006 with population densities of Heterodera glycines in nonfumigated and fumigated soil cores that were inoculated with 9,000 second-stage juveniles of $\mathrm{H}$. glycines. Log-transformed data were analyzed and original means and the corresponding standard errors are presented. Mean separation was conducted with PROC MIXED in SAS and indicated significance at $P=0.01(* *) ; P=0.10$ (T); or nonsignificance (n.s.). Nf: nonfumigated treatment in the field; Fum: fumigated treatment in the field. A, Cysts in each soil layer at initiation of the greenhouse experiment in nontreated (white bars) and fumigated (black bars) soil cores at initiation of the greenhouse experiment in 2006. B, Cyst population densities at harvest in the inoculated soil cores under different field and greenhouse fumigation treatments: the overall probability was $P<0.06$. C, Egg population densities under different field and greenhouse fumigation treatments: the overall probability was $P<0.02$. D, Root lengths $(\mathrm{cm})$ per $100 \mathrm{~g}$ of soil under different field and greenhouse fumigation treatments. 
pressiveness against Rhizoctonia solani AG3 when a soil was under corn monoculture, crop rotation, or grassland.

At ACRE, soil fumigation at initiation of the experiment removed the suppressiveness in the soil and rendered these plots highly conducive for the duration of the trials. Suppressiveness developed in nonfumigated soil in the third year under monoculture, and remained so in the following years during the 5-year duration. In the greenhouse, fumigation of the soil cores after transposition of them to the controlled environment did not alter conduciveness of the fumigated field soil, but eliminated the suppressiveness of the suppressive soil developed in the field conditions, as demonstrated by the high population density of $H$. glycines in these soils at harvest of the greenhouse experiment. Disturbance of the soil physical structure improved conditions for $H$. glycines in field-derived conducive soil, but did not impact nematode reproduction in field-derived suppressive soil. This was somewhat expected because the increasing effects of soil disturbance on nematode reproduction had been found in related projects in Indiana and other soybean producing states $(16,57,65)$. At the same time, foliar symptoms of SDS at ACRE were less severe in the suppressive than in the conducive soil. The nonincreased nematode population density in the disturbed, nonfumigated soil cores from nonfumigated field plots compared with the nondisturbed equivalent further supported the hypothesis of a microbial origin of the observed suppressiveness.

No biological selection criteria had been used to choose the fields for this study. In the entire research program, there was another site with suppressiveness against the disease complex. At that one site, factorial arrangements of the inoculations of $H$. glycines and $F$. virguliforme were made in two experiments plus in another experimental site (A. Westphal, unpublished data). Thus in total, suppressiveness against the disease complex was observed in experiments at two of three locations whether the pathogens occurred naturally or were artificially inoculated. Counting the two already mentioned examples of some type of suppressiveness in rotation trials with soybean and corn in fields with natural infestations (63), the number is even higher. It appears that a high frequency of suppressiveness developed under monoculture of soybean, especially when considering the results of a random survey for suppressiveness against $H$. glycines irrespective of crop sequence in Indiana and similar surveys against other plant-parasitic nematodes in other areas; in those studies, frequencies of 5 to $10 \%$ of the tested soils were found to be suppressive (40; A. Westphal, unpublished data). With the exception of one commercial field that was suppressive against $H$. glycines under a soybean-corn rotation (62), suppressive soils were observed under soybean monoculture. This may suggest that current production practices are not supporting the development of suppressive soils. The reasons for the high frequency of soil suppressiveness against $H$. glycines in Indiana under soybean monoculture remain unclear considering that suppressiveness against the nematode was rarely found in soybean monocultures in Minnesota $(6,7)$. The wide-spread occurrence of the nematode and its corresponding longer exposure time to the agroecosystem in Indiana compared with the presumably shorter exposure in Minnesota may be important for these developments.

It was surprising that the suppressive soil supported much healthier plants in regards not only to the SDS disease complex but probably also to other soilborne pathogens. Frequently, the benefit of soil suppressiveness is difficult to demonstrate because soils suppressive to one pathogen may be more conducive to others. For example in a $H$. schachtii-suppressive soil, other root rotters were greatly increased and compromised proper growth of host plant roots in such soil, partially challenging the hypothesis of biological suppression of the nematode (53). Despite the fact that soybean can be infected by various soilborne pathogens, root health of soybean plants in our study was greatly improved in the suppressive soil for the duration of the trial.

In summary, this project illustrates that suppressive systems can establish in intensive conventional agriculture. We do not propose to use monoculture soybean to reduce the occurrence of the SDS complex, for obvious challenges in soybean monocropping as outlined elsewhere (63). However, we do propose to use these natural disease-suppressing principles in a more knowledgeable way. Sustainable production of large acre/low value crops will rely on simple means to reduce the infection by soilborne pest. Improved use of soil suppressiveness will be an important part of sustainable systems.

\section{ACKNOWLEDGMENTS}

We thank J. Beaty, C. Fuhrman, C. Li, W. Li, H. Mehl, N. L. Snyder, J. Stockton, J. Young, and the farm crews at the research stations for technical assistance. The discussion of statistical procedures with

TABLE 2. Analysis of variance of the effects of field fumigation, collection method, sampling depth, and greenhouse treatment on population densities of Heterodera glycines and root length of soybean 'Spencer' in soil cores inoculated with 9,000 nematode second-stage juveniles (J2) in a greenhouse experiment in 2006 ${ }^{\mathrm{v}}$

\begin{tabular}{|c|c|c|c|c|c|c|c|}
\hline & \multirow[b]{2}{*}{ df } & \multicolumn{2}{|c|}{ Cysts/100 g of soil } & \multicolumn{2}{|c|}{ Eggs/100 g of soil } & \multicolumn{2}{|c|}{ Root length (cm) } \\
\hline & & Mean square & Probability & Mean square & Probability & Mean square & Probability \\
\hline Field fumigation $(\mathrm{FF})^{\mathrm{w}}$ & 1 & 0.940319 & 0.02 & 0.842047 & 0.16 & 0.039104 & 0.41 \\
\hline Collection method $(\mathrm{CM})^{\mathrm{x}}$ & 1 & 0.665288 & 0.04 & 2.714452 & 0.02 & 0.042630 & 0.39 \\
\hline Sampling depth $(\mathrm{SD})^{\mathrm{y}}$ & 2 & 0.712263 & 0.01 & 0.142558 & 0.74 & 0.385172 & 0.04 \\
\hline Error (c) & 6 & 0.075354 & 0.47 & 0.465067 & 0.01 & 0.065572 & $<0.01$ \\
\hline $\mathrm{CM} \times \mathrm{SD}$ & 2 & 0.054985 & 0.51 & 0.584384 & 0.03 & 0.014307 & 0.21 \\
\hline $\mathrm{FF} \times \mathrm{GF}$ & 1 & 0.938811 & $<0.01$ & 0.938532 & 0.02 & 0.037347 & 0.04 \\
\hline $\mathrm{CM} \times \mathrm{GF}$ & 1 & 0.401178 & 0.03 & 0.178287 & 0.29 & 0.094164 & $<0.01$ \\
\hline $\mathrm{FF} \times \mathrm{CM} \times \mathrm{GF}$ & 1 & 0.296116 & 0.06 & 0.896055 & 0.02 & 0.008860 & 0.32 \\
\hline $\mathrm{GT} \times \mathrm{SD}$ & 2 & 1.016615 & $<0.01$ & 1.418895 & $<0.01$ & 0.022876 & 0.08 \\
\hline $\mathrm{CM} \times \mathrm{GF} \times \mathrm{SD}$ & 2 & 0.144464 & 0.18 & 0.160594 & 0.36 & 0.043126 & 0.01 \\
\hline Pooled error $(d+e+f)$ & 48 & 0.079972 & $\ldots$ & 0.154349 & $\ldots$ & 0.008809 & $\ldots$ \\
\hline
\end{tabular}

${ }^{\mathrm{v}}$ The log-transformed data $\left(\log _{10}(x+1)\right)$ were entered into the analysis; only factors or interactions significant for at least one parameter of the analysis of data from cores inoculated with H. glycines are shown.

${ }^{w}$ Field plots, from which the soil cores were collected to conduct the greenhouse experiment, had been left nonfumigated or fumigated with methyl bromide at $450 \mathrm{~kg} / \mathrm{ha}$ before all plots were inoculated with Fusarium virguliforme on grain sorghum carrier in 2003.

${ }^{\mathrm{x}}$ Soil cores (10-cm diameter and 30-cm depth) were collected from field plots either nondisturbed or disturbed, which meant that the original structure of soil in the field had been mechanically broken in each 10-cm depth layer and soil then repacked into similar containers after passage through a sieve of $6 \mathrm{~mm}$ aperture.

${ }^{y}$ Layers of three depths ( 0 to 10,10 to 20 , and 20 to $30 \mathrm{~cm}$ ) were processed separately.

${ }^{\mathrm{z}}$ Soil cores were left nonfumigated or were fumigated with methyl bromide at $1,070 \mathrm{~kg} / \mathrm{ha}$ before inoculation with $9,000 \mathrm{~J} 2 \mathrm{of} \mathrm{H}$. glycines. 
J. Santini is greatly appreciated. Support by the Indiana Soybean Alliance and the North Central Soybean Research Program in addition to a grant by the NRICGP within USDA-CSREES (grant 2002-02802) is greatly appreciated. Support by the AgSpectrum and the College of Agriculture, Purdue University is acknowledged.

\section{LITERATURE CITED}

1. Alabouvette, C. 1986. Fusarium wilt suppressive soils from the Châteaurenard region: Review of a 10-year study. Agronomie 6:273-284

2. Aoki, T., O'Donnell, K., Homma, Y., and Lattanzi, A. R. 2003. Suddendeath syndrome of soybean is caused by two morphologically and phylogenetically distinct species within Fusarium solani species complex-F. virguliforme in North America and F. tucumaniae in South America. Mycologia 95:660-684.

3. Baker, K. F., and Cook, R. J. 1974. Biological Control of Plant Pathogens. American Phytopathological Society, St. Paul, MN.

4. Broadbent, P., and Baker, K. F. 1974. Behaviour of Phytophthora cinnamomi in soils suppressive and conducive to root rot. Aust. J. Agric. Res. 25:121-137.

5. Caswell, E. P., Thomason, I. J., and McKinney, H. E. 1985. Extraction of cysts and eggs of Heterodera schachtii from soil with an assessment of extraction efficiency. J. Nematol. 17:337-340.

6. Chen, S. 2007. Suppression of Heterodera glycines in soils from fields with long-term soybean monoculture. Biocontrol Sci. Technol. 17:125-134.

7. Chen, S. 2007. Tillage and crop sequence effects on Heterodera glycines and soybean yields. Agron. J. 99:797-807.

8. Chet, I., and Baker, R. 1980. Induction of suppressiveness to Rhizoctonia solani in soil. Phytopathology 70:994-998.

9. Cook, R. J., and Baker, K. F. 1983. The Nature and Practice of Biological Control of Plant Pathogens. American Phytopathological Society, St. Paul, $\mathrm{MN}$.

10. Covert, S. F., Aoki, T., O'Donnell, K., Starkey, D., Holliday, A., Geiser, D. M., Cheung, F., Town, C., Strom, A., Juba, J., Scandiani, M., and Yang, X. B. 2007. Sexual reproduction in the sudden death syndrome pathogen Fusarium tucumaniae. Fungal Genet. Biol. 44:799-807.

11. De Farias Neto, A., Hartman, G. L., Pedersen, W. L., Li, S., Bollero, G., and Diers, B. W. 2006. Irrigation and inoculation treatments that increase the severity of soybean sudden death syndrome in the field. Crop Sci. 46:2547-2554

12. Domíguez, J., Negrin, M. A., and Rodríguez, C. M. 2001. Aggregate water-stability, particle size and soil solution properties in conducive and suppressive soils to Fusarium wilt of banana from Canary Islands (Spain). Soil Biol. Biochem. 33:449-455.

13. Faghihi, J., and Ferris, J. M. 2000. An efficient new devise to release eggs from Heterodera glycines. J. Nematol. 32:411-413.

14. Fehr, W. R., Caviness, C. E., Burmood, D. T., and Pennington, J. S. 1971. Stage of development descriptions for soybeans, Glycine max (L.) Merrill. Crop Sci. 11:929-931.

15. Garbeva, P., van Veen, J. A., and van Elsas, J. D. 2004. Microbial diversity in soil: Selection of microbial populations by plant and soil type and implications for disease suppressiveness. Annu. Rev. Phytopathol. 42:243270.

16. Gavassoni, W. L., Tylka, G. L., and Munkvold, G. P. 2001. Relationship between tillage and spatial patterns of Heterodera glycines. Phytopathology 91:534-545.

17. Grau, C. R., Dorrance, A. E., Bond, J., and Russin, J. S. 2004. Soybean fungal diseases. Pages 679-763 in: Soybean Improvement, Production, and Uses. Agronomy 16, 3rd ed. H. R. Boerma and J. E. Specht, eds. ASA, CSSA, SSSA Press, Madison, WI.

18. Gray, L. E., and Achenbach, L. A. 1996. Severity of foliar symptoms and root and crown rot of soybean inoculated with various isolates and inoculum rates of Fusarium solani. Plant Dis. 80:1197-1199.

19. Höper, H., Steinberg, C., and Alabouvette, C. 1995. Involvement of clay type and $\mathrm{pH}$ in the mechanisms of soil suppressiveness to Fusarium wilt of flax. Soil Biol. Biochem. 27:955-967.

20. Kerry, B. R. 1987. Biological Control. Pages 233-263 in: Principles and Practice of Nematode Control in Crops. R. H. Brown and B. R. Kerry, eds. Academic Press, Sydney, Australia.

21. Kerry, B. R., and Crump, D. H. 1977. Observations on fungal parasites of females and eggs of the cereal cyst nematode, Heterodera avenae, and other cyst nematodes. Nematologica 23:193-201.

22. Kok, C. J., Pappert, A., and Hok-A-Hin, C. H. 2001. Microflora of Meloidogyne egg masses: Species composition, population density and effect on the biocontrol agent Verticillium chlamydosporium (Goddard). Nematology 3:729-734.

23. Li, S., Hartman, G. L., and Chen, Y. 2009. Evaluation of aggressiveness of Fusarium virguliforme isolates that cause sudden death syndrome. J. Plant Pathol. 91:77-86.
24. Loux, M. M., Stachler, J. M., Johnson, W. G., Nice, G. R. W., and Bauman, T. 2004. Weed Control Guide for Ohio Field Crops. The Ohio State University, Columbus, $\mathrm{OH}$.

25. Luo, Y., Meyer, O., Lightfoot, D. A., and Schmidt, M. E. 1999. Root colonization of soybean cultivars in the field by Fusarium solani f. sp. glycines. Plant Dis. 83:1155-1159.

26. Martinez, C., Michaud, M., Belanger, R. B., and Tweddell, R. J. 2002. Identification of soils suppressive against Helminthosporium solani, the causal agent of potato silver scurf. Soil Biol. Biochem. 34:1861-1868.

27. Mazzola, M. 2002. Mechanisms of natural soil suppressiveness to soilborne diseases. Antonie van Leeuwenhoek 81:557-564.

28. Mazzola, M. 2004. Assessment and management of soil microbial community structure for disease suppression. Annu. Rev. Phytopathol. 42:35-59.

29. McMichael, R. L., and Burke, J. J. 1994. Metabolic activity of cotton roots in response to temperature. Environ. Exp. Bot. 49:453-460.

30. Menzies, J. D. 1959. Occurrence and transfer of a biological factor in soil that suppress potato scab. Phytopathology 49:648-652.

31. Murakami, H., Tsushima, T., and Shishido, Y. 2000. Soil suppressiveness to clubroot disease of Chinese cabbage caused by Plasmodiophora brassicae. Soil Biol. Biochem. 32:1637-1642.

32. Niblack, T. L. 2005. Soybean cyst nematode management reconsidered. Plant Dis. 89:1020-1026.

33. Niblack, T. L., Arelli, P. R., Noel, G. R., Opperman, C. H., Orf, J. H., Schmitt, D. P., Shannon, J. G., and Tylka, G. L. 2002. A revised classification scheme for genetically diverse populations of Heterodera glycines. J. Nematol. 34:279-288

34. Niblack, T. L., Baker, N. K., and Norton, D. C. 1992. Soybean yield losses due to Heterodera glycines in Iowa. Plant Dis. 76:943-948.

35. Nishiyama, M., Shiomi, Y., Suzuki, S., and Marumoto, T. 1999. Suppression of growth of Ralstonia solanacearum, tomato bacterial wilt agent, on/in tomato seedlings cultivated in a suppressive soil. Soil Sci. Plant Nutr. 45:79-87.

36. Oyarzun, P. J., Dijst, G., Zoon, F. C., and Maas, P. W. 1997. Comparison of soil receptivity to Thielaviopsis basicola, Aphanomyces euteiches, and Fusarium solani f. sp. pisi causing root rot of pea. Phytopathology 87:534-541.

37. Peng, H. X., Sivasithamparam, K., and Turner, D. W. 1999. Chlamydospore germination and Fusarium wilt of banana plantlets in suppressive and conducive soils are affected by soil physical and chemical factors. Soil Biol. Biochem. 31:1363-1374.

38. Persson, L., Larsson-Wikström, M., and Gerhardson, B. 1999. Assessment of soil suppressiveness to Aphanomyces root rot of pea. Plant Dis. 83:1108-1112.

39. Pfeffer, H., and Lüth, P. 1990. Der Einfluss einer Rotkleemonokultur auf das antiphytopathogene Potential des Bodens in bezug auf Sclerotinia trifoliorum Erikss. Nachrichtenblatt Pflanzenschutz 44:214-216.

40. Pyrowolakis, A., Westphal, A., Sikora, R. A., and Becker, J. O. 2002. Identification of root-knot nematode suppressive soils. Appl. Soil Ecol. 19:51-56.

41. Roy, K. W. 1997. Sporulation of Fusarium solani f. sp. glycines, causal agent of sudden death syndrome, on soybeans in the Midwestern and Southern United States. Plant Dis. 81:566-569.

42. Roy, K. W., Patel, M. V., and Baird, R. E. 2000. Colonization of Heterodera glycines cysts by Fusarium solani form A, the cause of sudden death syndrome, and other fusaria in soybean fields in the Midwestern and southern United States. Phytoprotection 81:57-67.

43. Rupe, J. C., Robbins, R. T., and Gbur, E. E., Jr. 1997. Effect of crop rotation on soil population densities of Fusarium solani and Heterodera glycines and on the development of sudden death syndrome of soybean. Crop Prot. 16:575-580.

44. Ryan, A. D., Kinkel, L. L., and Schottel, J. L. 2004. Effect of pathogen isolate, potato cultivar, and antagonistic strain on potato scab severity and biological control. Biocontrol Sci. Technol. 14:301-311.

45. Samac, D. A., and Kinkel, L. L. 2001. Suppression of the root-lesion nematode (Pratylenchus penetrans) in alfalfa (Medicago sativa) by Streptomyces spp. Plant Soil 235:35-44.

46. Seyb, A., and Westphal, A. 2008. Seed and planting treatments for managing soybean cyst nematode and sudden death syndrome in soybean in North-central Indiana, 2007. Plant Dis. Manage. Rep., Vol. 2: ST001. American Phytopathological Society, St. Paul, MN.

47. Stirling, G. R., and Mankau, R. 1979. Mode of parasitism of Meloidogyne and other nematode eggs by Dactylella oviparasitica. J. Nematol. 11:282288.

48. Van Elsas, J. D., Garbeva, P., and Salles, J. 2002. Effects of agronomical measures on the microbial diversity of soils as related to suppression of soil-borne plant pathogens. Biodegradation 13:29-40.

49. Vick, C. M., Bond, J. P., Chong, S. K., and Russin, J. S. 2006. Response of soybean sudden death syndrome to tillage and cultivar. Can. J. Plant Pathol. 28:77-83. 
50. Weibelzahl-Fulton, E., Dickson, D. W., and Whitty, E. B. 1996. Suppression of Meloidogyne incognita and M. javanica by Pasteuria penetrans in field soil. J. Nematol. 28:43-49.

51. Weller, D. M., Raaijmakers, J. M., McSpadden Gardener, B. B., and Thomashow, L. S. 2002. Microbial populations responsible for specific soil suppressiveness to plant pathogens. Annu. Rev. Phytopathol. 40:309348.

52. Westphal, A. 2005. Detection and description of soils with specific nematode suppressiveness. J. Nematol. 37:121-130.

53. Westphal, A., and Becker, J. O. 1999. Biological suppression and natural population decline of Heterodera schachtii in a California field. Phytopathology 89:434-440.

54. Westphal, A., and Becker, J. O. 2001. Components of soil suppressiveness against Heterodera schachtii. Soil Biol. Biochem. 33:9-16.

55. Westphal A., and Becker, J. O. 2001. Soil suppressiveness to Heterodera schachtii under different cropping sequences. Nematology 3:551-558.

56. Westphal, A., and Smart, J. R. 2003. Depth distribution of Rotylenchulus reniformis under different tillage and crop sequence systems. Phytopathology 93:1182-1189.

57. Westphal, A., Xing, L. J., Pillsbury, R., and Vyn, T. J. 2009. Effects of tillage on population densities of Heterodera glycines. Field Crops Res. 113:218-226.

58. Workneh, F., Tylka, G. L., Yang, X. B., Faghihi, J., and Ferris, J. M. 1999. Regional assessment of soybean brown stem rot, Phytophthora sojae, and
Heterodera glycines using area-frame sampling: Prevalence and effects of tillage. Phytopathology 89:204-211.

59. Wrather, J. A., and Koenning, S. R. 2009. Effects of diseases on soybean yields in the United States 1996 to 2007. Plant Health Progress. Published online. doi:10.1094/PHP-2009-0401-01-RS.

60. Xiao, K., Kinkel, L. L., and Samac, D. A. 2002. Biological control of Phytophthora root rots on alfalfa and soybean with Streptomyces. Biol. Control 23:285-295.

61. Xing, L. J., and Westphal, A. 2006. Interaction of Fusarium solani f. sp. glycines and Heterodera glycines in sudden death syndrome of soybean. Phytopathology 96:763-770.

62. Xing, L. J., and Westphal, A. 2006. Transferring soil suppressiveness against Heterodera glycines under field conditions. (Abstr.) J. Nematol. 38:302.

63. Xing, L. J., and Westphal, A. 2009. Effects of crop rotation of soybean with corn on severity of sudden death syndrome and population densities of Heterodera glycines in naturally infested soil. Field Crops Res. 112:107-117.

64. Yin, B., Valinsky, L., Becker, J. O., and Bornemann, J. 2003. Identification of fungal rDNA associated with soil suppressiveness against Heterodera schachtii using oligonucleotide fingerprinting. Phytopathology 93:1006-1013.

65. Young, L. D. 1987. Effects of soil disturbance on reproduction of Heterodera glycines. J. Nematol. 19:142-143. 